\title{
Calcium antagonists and good results: Association or causation?
}

\author{
Donald D. Glower, MD
}

See related articles on pages 622 and 755.

From Duke University Medical Center, Durham, NC.

Received for publication Oct 30, 2003; accepted for publication Nov 3, 2003.

Address for reprints: Donald D. Glower, MD, Duke University Medical Center, Box 3851, Durham, NC 27710 (E-mail: glowe001.mc.duke.edu).

J Thorac Cardiovasc Surg 2004;127:625-6

0022-5223/\$30.00

Copyright (C) 2004 by The American Association for Thoracic Surgery

doi:10.1016/j.jtcvs.2003.11.002

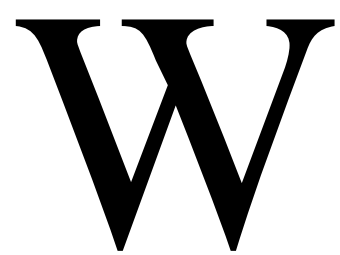

ijeysundera and colleagues ${ }^{1}$ retrospectively examined the effects of preoperative calcium antagonists on operative mortality and postoperative morbidity after cardiac surgery. Results, including propensity score analysis, showed significant reduction in operative mortality associated with use of calcium antagonists. Wijeysundera and colleagues ${ }^{1}$ concluded that a large randomized trial of perioperative calcium antagonists is indicated to test the hypothesis that calcium antagonists decrease perioperative morbidity and mortality.

This study is important because it is the largest study to examine the effects of calcium antagonists on perioperative mortality after cardiac surgery. The results are also important in that the risks versus benefits of calcium antagonists in cardiac patients remain controversial. The reduction in mortality was relatively large (roughly 50\%), again implying that these results could save many lives.

This study unfortunately represents the pinnacle of current cardiac surgical research, a retrospective search for statistical associations. In this study, preoperative use of calcium antagonists was statistically associated with lower perioperative mortality. As Wijeysundera and colleagues ${ }^{1}$ admit, however, this retrospective search for statistical association was complicated by the fact that the two treatment groups were unmatched and may have been tainted by selection bias. Multivariable propensity score analysis was therefore used, as perhaps the most sophisticated statistical weapon in the cardiac surgical arsenal to attempt to correct for selection bias.

The problem is that association does not prove causality, even when propensity score analysis is used. There are classic examples in both remote and recent medical research of confusion between association and causality. Take, for example, the autopsy study ridiculed by statisticians (but not all physicians) demonstrating an inverse relationship between cancer and tuberculosis, ${ }^{2}$ with the conclusion that tuberculosis prevents cancer. Take also, for example, the recent study (still often quoted) showing a significant association between pulmonary artery catheter use and hospital mortality in intensive care patients, with the conclusion that pulmonary artery catheters kill patients. ${ }^{3,4}$

One important test for causality is to examine whether plausible mechanisms of causality can be demonstrated. The difficulty finding a mechanism by which tuberculosis prevents cancer should raise concerns. ${ }^{2}$ Similarly, the fact that pulmonary artery catheters kill primarily by pulmonary artery rupture and ventricular arrhythmia should raise concerns when, in fact, few patients dying after pulmonary artery catheter use suffered either of these consequences. ${ }^{3,4}$

In the study of Wijeysundera and colleagues, ${ }^{1}$ it is similarly challenging to guess how calcium antagonists might improve mortality associated with cardiac surgery. Wijeysundera and colleagues ${ }^{1}$ propose the mechanism of preventing ischemia and arrhythmias. Calcium antagonists are known to have value in treating hypertension, angina, tachycardia, and possibly myocardial ischemia. ${ }^{5,6}$ However, calcium antagonists have been disappointing in failing to consistently prevent atrial fibrillation, improve graft patency, ${ }^{7}$ or improve morbidity or mortality from heart failure or coronary disease. ${ }^{8,9}$ Although effects vary with the type of calcium antagonist used, calcium antagonists are relatively contraindicated in patients with bradycardia, ventricular dysfunction, or hypotension. So how do calcium-channel blockers im- 
prove cardiac surgical mortality? Although further investigation is clearly indicated, now may be too soon to recommend more aggressive use of calcium antagonists before cardiac surgery.

For infections, proof of causality requires satisfaction of the Koch postulates. For noninfectious causality, proof ultimately means a prospective, randomized study. Achieving such studies requires funding, however, and funding for clinical research in cardiac surgery is remarkably absent. Why? First, the National Heart, Lung and Blood Institute decided nearly 15 years ago to invest federal dollars into basic research rather than clinical research. This decision may have been wise in the long run, but it has definite short-term consequences. Second, the cardiac surgical market is too small to be worth the investment for most private corporations, such as the pharmaceutical industry and the medical device industry. Because neither of these two funding problems is likely to change soon, cardiac surgeons must make the best of what we have. The onus will always remain on the reader and the responsible investigator not to confuse association and causation.

\section{References}

1. Wijeysundera DN, Beattie WS, Rao V, Ivanov J, Karkouti K. Calcium antagonists are associated with reduced mortality after cardiac surgery: a propensity analysis. J Thorac Cardiovasc Surg. 2004;127:755-62.
2. Pearl R. Cancer and tuberculosis. Am J Hyg. 1929;9:97-159.

3. Connors AF, Speroff T, Dawson NV, Thomas C, Harrell FE, Wagner D, et al. The effectiveness of right heart catheterization in the initial care of critically ill patients. SUPPORT Investigators. JAMA. 1996;276:88997.

4. Dalen JE, Bone RC. Is it time to pull the pulmonary artery catheter? JAMA. 1996;276:916-8.

5. Gersh BJ, Braunwald E, Bonow RO. Chronic coronary artery disease. In: Braunwald E, Zipes DP, Libby P, editors. Heart disease. Philadelphia: WB Saunders; 2001. p. 1293-7.

6. Rinaldi CA, Linka AZ, Masani ND, Avery PG, Jones E, Saunders H, et al. Randomized, double-blind crossover study to investigate the effects of amlodipine and isosorbide mononitrate on the time course and severity of exercise-induced myocardial stunning. Circulation. 1998;98: 749-56.

7. Gaudino M, Glieca F, Luciani N, Alessandrini F, Possati G. Clinical and angiographic effects of chronic calcium channel blocker therapy continued beyond first postoperative year in patients with radial artery grafts: results of a prospective randomized investigation. Circulation. 2001;104(12 Suppl 1):I64-7.

8. Villani GQ, Piepoli MF, Terracciano C, Capucci A. Effects of diltiazem pretreatment on direct-current cardioversion in patients with persistent atrial fibrillation: a single-blind, randomized, controlled study. Am Heart J. 2000;140:437-43.

9. ALLHAT Officers and Coordinators for the ALLHAT Collaborative Research Group-The Antihypertensive and Lipid-Lowering Treatment to Prevent Heart Attack Trial. Major outcomes in high-risk hypertensive patients randomized to angiotensin-converting enzyme inhibitor or calcium channel blocker vs diuretic: The Antihypertensive and LipidLowering Treatment to Prevent Heart Attack Trial (ALLHAT). JAMA. 2002;288:2981-97.

\section{Online-www.aats.org}

Now you can get The Journal of Thoracic and Cardiovascular Surgery online. The Journal online brings you faster delivery time, easy searching of current and back issues, links to PubMed, AATS, WTSA, and other important sites, and more. Visit the Journal online today.

\section{Receive tables of contents by e-mail}

To receive the tables of contents by e-mail, sign up through our Web site at http://www.mosby.com/jtcvs

Choose E-mail Notification

Simply type your e-mail address in the box and click the Subscribe button. Alternatively, you may send an e-mail message to majordomo@mosby.com. Leave the subject line blank and type the following as the body of your message: subscribe jtcvs_toc You will receive an e-mail to confirm that you have been added to the mailing list.

Note that TOC e-mails will be sent out when a new issue is posted to the Web site. 